\title{
Comenius's Educatio in the Perspective of Leisure Time Pedagogy \\ Helena Zbudilová
}

DOI: $10.32725 /$ cetv.2021.038

\begin{abstract}
:
The article focuses on the pedagogical legacy of John Amos Comenius (1592-1670) from the point of view of leisure time pedagogy. Comenius's contribution is sought in the perspective which considers the whole as a basic educational principle and in the direction of man towards true humanity as the basic meaning of education. The interpretation is based on the Christian holistic concept and the theological grounding of the interpretation of leisure time. The main roots of Comenius's conception of education are found in the psychagogic dimension of educatio and in the scholé phenomenon. The overall meaning of education is sought in its 'Sunday' purpose. The text deals with the analysis of selected author's works through the prism of the specifics of leisure time pedagogy and evaluates Comenius's contribution as a philosopher, theologian, and a leisure time pedagogue. Leisure time pedagogy is perceived as education with a psychagogical and philosophical-religious dimension.
\end{abstract}

Keywords: John Amos Comenius, philosophy of education, leisure time pedagogy, religious education, paideia, educatio, scholé, open soul, schola pansophica (pansophic school, omniscient school), holistic education, psychagogy

Pampaedia ponders about the universal education of the spirit and the establishment of an order in matters of a lifetime

in order to make the mind of every human (being pleasantly employed in all its age levels) a garden of joy...

(foreword from the title page of Part 4 of General Consultation on the Reform of Human Affairs)

With his work, John Amos Comenius created a comprehensive philosophy of education based on a theological foundation. He understood the whole world as the 'sub specie educationis' and the human being as the 'sub specie Dei, the sub specie of the whole sense.' Through theology and traditional philosophy, he comes to a completely innovative goal in his time - 'building humanity 
as a unified force called to complete the world. ${ }^{1}$ He understands education as the direction of man towards true humanity which God has assigned to him. The decisive educational principle for him is 'omnino' (respect for the whole). The notions of humanity and the whole, so much needed by man in today's postmodern age, are becoming the main vanishing points of our search for Comenius from the perspective of stimuli for leisure pedagogy. We build on the theological grounding of the interpretation of leisure time, on the Christian holistic concept. We place Comenius's concept of leisure time primarily in the mindset of Josef Pieper. Thus, the philosophical and theological basis of the first inspirer of the origin of leisure time at the turn of the Middle Ages and the Modern Age is connected with one of the first thinkers dealing with leisure time (the first generation) of the $20^{\text {th }}$ century. Pieper's definition of leisure time from his pioneering work Muße und Kult (1948) emphasises the above mentioned concepts: 'The purpose of leisure time is to remain human, to understand and to realize oneself as a being who is focused on the whole of reality.' ${ }^{2}$ How Pieper's Christian classical view of leisure time (written by a Catholic) resonates in the work of the Protestant Comenius will be clarified through the comparison of the scholé phenomenon as the philosophical basis of education in leisure time and the understanding of the relationship between work and leisure. First, however, it is necessary to focus specifically on Comenius's conception of education and the main archetypes of education on which the idea was based. These are two archetypal expressions of psychagogy (philosophical and biblical): Platonic paideia and Christian educatio as forms of care for the soul. We remain with the concept of the soul with regard to Pieper's definition of leisure time as the 'state of the soul' ${ }^{3}$ and the analogous use of the term 'open soul' by Comenius and Pieper.

\section{Platonic Paideia and Comenius}

Comenius continues the tradition of ancient philosophy through Augustinianism. Although Comenius probably did not know Plato from direct reading, it became his basic philosophical-pedagogical starting point. In Pampaedia, the Platonic framework emerges quite clearly as a defining point of Comenius's philosophy of education. ${ }^{4}$ If Platonic paideia implies the understanding of education as the emergence of man from the play of shadows and dreams to the Light, Comenius finds here a common central idea of the soul as a principle of the integrity of life, which relates to the whole. A comparison can be made between Platonic paideia and Comenius's idea of pampaedia. The roots of Comenius's complete reformational educational effort are connected by the same motif, which identifies the process of education with the path from dreams to being, from untruth to truth. He also interprets truth as order and human life in truth as life in order. ${ }^{5}$ At the same time, they are united by a common goal. Plato's philosophy, paideia, as well as Comenius's pampaedia arose in response to the value crisis of society in order to reform this situation. Plato transferred the meaning of paideia to the ground of the Greek state - polis; Comenius transferred his pampaedia to the ground of the world. If Platonic paideia is 'care for the soul', the systematic guidance of gifted individuals to see the truth, that is, the world of ideas, Comenius's pampaedia becomes 'care for the soul'. In the demand for the education of all and everything

\footnotetext{
Jan PATOČKA, Komeniologické studie III, Praha: OIKOYMENH, 2003, p. 540.

2 Josef PIEPER, Volný čas, vzdělání, moudrost, Praha: Křestanská akademie Praha, 1992, p. 15; Josef PIEPER, Leisure: The Basis of Culture, San Francisco: Ignatius Press, 2009, p. 46.

Ibid., 1992, p. 14; ibid., 2009, p. 46.

Cf. Miloslav BEDNÁŘ, České myšlení, Praha: Filosofia, 1996, p. 60.

Cf. Jan PATOČKA, Komeniologické studie III..., p. 373.
} 
from the point of view of the overall meaning of all being (omnes, omnia, omnino) in Pampaedia, Comenius democratises the Platonic ideal of philosophy as education. ${ }^{6}$ In Comenius's concept of education expressed by the intention omnes omnia omnino (to teach everyone everything) Klaus Schaller emphasises omnino, respect for the whole (with regard to the whole, from the perspective of the whole). According to him, this emphasis opens up new horizons of education and new beginnings in comeniology. ${ }^{7}$ For Plato, the completion of the goal of education concerned only a small number of philosophers. According to Comenius, though, education, which enables one to see ideas, must concern everyone. Comenius further surpassed Platonism through scheduled activity - a complete reform that concerns the whole of human society. It is about caring for creation in the broadest sense. ${ }^{8}$ The fundamental difference is a different ontological basis. Comenius's conception grows out of the second cornerstone of European culture - Christianity. The most up-to-date comparison of both philosophical-educational concepts is provided by the book Mezi filosofí a teologií výchovy by Zuzana Svobodová and Andrea Blašćíková. While in the case of paideia the inequality between God and man was perceived as an insurmountable boundary, and this instance was impersonal and anonymous, Comenius's Christian education is about the revelation of God in Christ. The cause and norm of the turn in Plato was true being. In Comenius, it is the world, especially nature in its teleological structure. In the Greek world, it was about a rivalry between the principles of chaos and order, light and darkness, life and death. In Comenius's Christian world, this struggle is overcome. History becomes the history of salvation. ${ }^{10}$ Pavel Floss describes Comenius's philosophical thinking as one of the peaks of the Christianisation of Neoplatonism. From the point of view of the aim of this article, let us consider the notion of epistrophe, as Comenius gave the term a new meaning which breaks through the framework of Neoplatonism. In Neoplatonics, epistrophe is the return to the absolute, one does not create anything. However, Comenius understands epistrophe creatively. He sees it as a creative force that is inherent to man. It is not just about remembering. It is about creating new things. It is a fruitful thinking that is inherent to man only. For Comenius, epistrophe is something which is man's own creative domain, the field of his work, creativity, education. It is something which, in fact, creates other 'worlds', namely the worlds of human technical, organisational, moral, and historical activity; it has a positive meaning. ${ }^{11}$

\section{Christian Educatio and Comenius}

Comenius's term educatio grows out of Christianity, continuing the tradition of the Czech Reformation (especially the Unity of Brethren). The tradition is reflected in the consistent democratism of his educational concept. The legacy of the Unity of Brethren lies in Comenius's optimistic view of human nature (in contrast to the orthodox Protestant conception of radically corrupt human nature). ${ }^{12}$ The purpose of Christian educatio (guidance) is to show man the way of acting which is truly human, which is about following Christ, and which corresponds to his essential purpose

6 Cf. BEDNÁ̌̆, České myšlení..., p. 63.

7 Cf. Klaus SCHALLER, Shrnutí a závěrečné slovo, in: Jan Amos Komenský - odkaz kultuře vzdělávání. Př́spěvky z mezinárodní konference Odkaz Jana Amose Komenského kultuře vzdělávání (Praha, 15.-17. listopadu 2007), Praha: Academia, 2009, p. 766.

8 Cf. Dalibor VIK, Konzultace s Komenským na prahu světověku. Nástin hlavních rysů Paloušovy komeniologie (II.), Paideia: Philosophical E-Journal of Charles University 1/2020, p. 9. Available at: https://ojs.cuni.cz/paideia/article/view/1737, cited $2^{\text {nd }}$ August 2021.

9 Zuzana SVOBODOVÁ and Andrea BLAŠČÍKOVÁ, Mezi filosofí a teologií výchovy. Dialog k odkazu Radima Palouše, Praha: Karolinum, 2021.

10 Ibid., pp. 17-25.

11 Cf. Jan PATOČKA, Komeniologické studie I, Praha: OIKOYMENH, 1997, p. 182.

12 Cf. Ibid, p. 222. 
to succeed sub specie Dei. ${ }^{13}$ It is a matter of the reforming (man should be reformed by renewal), of one's liberation in the Truth represented by Christ. Comenius's idea of pansophia brings a new conception of education. His educational-reformative efforts represent educatio in its true sense, that is, guiding a person and taking him out of everything improper. Comenius implies the ascendance of humanity and intends to cultivate or reform it not only in the individual and holistic sense, but also in a global one. This is indicated by the prefix pan itself. In the work General Consultation on the Reform of Human Affairs, Comenius places this prefix in front of every human effort within its grounding in relation to other people and to the whole of humanity. ${ }^{14}$ The purpose of education is salvation. Comenius's theology is built on the triadism of God the Father - the Son of God - the Holy Spirit. For Comenius, the religio means establishing a broken bond, repairing a broken relationship with God. ${ }^{15}$ The emphasis is on a simple life inspired by the Gospel. For Comenius, faith is not an escape into the privacy of the human heart, but a common sharing of the event concerning the incarnation of the Logos (Christ, the Sense) into the history of the world. Comenius advocated a universal and supra-denominational form of Christianity. Josef Válka calls his concept 'non-confessional' or 'supra-confessional' religion. ${ }^{16}$ This appeal, which should lead to the unification of Christians under one common banner, sounds loudest from Comenius's work Pannuthesia.

\section{Scholé}

Greek schole (leisure) is the space and opportunity for Platonic paideia and Christian educatio. It is free time which has an ontological mission. It gives the opportunity to see the world as a whole and meet the hitherto hidden truth about the world. The task of schole is to transcend the boundaries of everyday life, that is, transcendence. In terms of education, this regards the Sunday mission of the school which lies in awakening of a person. One should be reach the awareness of who he is and how to live truly humanly. ${ }^{17}$ The essential task of education is therefore release from busyness into the sacred space of the schole in which real education takes place and the true freedom of man springs. Man's mission, then, is to 'be Sunday-like', to dwell on the essence, to be open to the message from above. ${ }^{18}$

\section{Scholé and Pieper}

Pieper, a great expert on the work of Thomas Aquinas, calls (in accordance with him) for Greek paideia and Christian educatio not to be in irreconcilable conflict. Both are Sunday affairs, standing outside the daily care of basic human needs. At the centre of Platonic paideia is the idea of Good (the greatest good - Agathon). In Christian educatio the soul is oriented towards Meaning which is God, the greatest Good. Pieper is a supporter and advocate of the classic concept of leisure time which continues the ancient tradition of scholé. At the same time, in his theory of leisure time, he is inspired by medieval philosophy. The basis of his conception of leisure time is Plato's scholé (which leads man to transcendence), and the accentuations of Christian contemplation adopted from Thomas Aquinas. He considers leisure time to be an essential element which constitutes

13 Cf. Radim PALOUŠ, K filosofii výchovy (východiska fundamentální agogiky), Praha: Státní pedagogické nakladatelství, 1991 , p. 16.

14 Cf. Jan HÁBL, Lekce z lidskosti v životě a díle Jana Amose Komenského, Hradec Králové: Gaudeamus, 2010, p. 112.

15 Cf. Radim PALOUŠ, Komenský - náboženský myslitel, Studia Comeniana et Historica 51/1994, pp. 7-8.

16 Cf. Josef VÁLKA, Komenský a nadkonfesijní křestanství, Studia Comeniana et Historica 51/, 1994, pp. 124-126.

17 Cf. SVOBODOVÁ and BLAŠČÍKOVÁ, Mezi filosofií a teologií výchovy..., pp. 26-36.

18 Cf. Radim PALOUŠ, Heretická škola, Praha: Karolinum, 2009, p. 11. 
culture. ${ }^{19}$ Pieper perceives the path to free time through the search for God and the fulfilment of humanity. According to him, leisure time is a state of the soul which enables one to seek God. Leisure time is outside ratio (logical thinking). Its intellectus (observation) has no time limits; it goes on constantly. ${ }^{20}$ It thus appears in human life as a whole. For Pieper, the source of leisure time is worship, cult. According to him, the peak of experience is a holiday in the sense of deviating from everyday life and fulfilling the joyful celebration of life (through liturgy). ${ }^{21}$ Pieper saw leisure time as 'a form of silence that is a prerequisite for the perception of reality' and as 'an attitude of acceptive perception, observative contemplative immersion in being. ${ }^{22}$ Within the classical Christian concept of leisure time, Pieper presents a rhythmic type of its definition. The basis of this approach is to respect the natural alternation of activity and rest. ${ }^{23}$

\section{Scholé and Comenius}

The main roots and general meaning of Comenius's conception of thinking about education lie in the Sunday purpose of paideia or educatio. ${ }^{24}$ Comenius insists on the 'Sunday' designation of education and its institution - the school. His universal school system, in which everyone should learn everything, remains in this 'Sunday spirit'. Likewise, his education, as a lifelong event, is essentially 'Sunday-like. ${ }^{25}$ According to Comenius, Sunday's school mission awakens man to self-awareness and awareness of his mission as a person, an instrument of the genesis of creation. ${ }^{26}$ From the point of view of leisure time pedagogy, Comenius's phenomenon of scholé is closely connected with religio. His schola - institution - is a space in which the pupil, in addition to preparation for everyday life, is primarily brought up to accept the sacred. The most important educational events take place in the schole interval. In his work, for the first time in the history of the theory of education, Comenius presents the idea of the polarisation of teaching time and leisure time, the separation of working time and leisure time.

\section{Leisure Time Versus Work: Pieper, Comenius}

Pieper does not identify leisure time with non-working hours, weekends, holidays. In his conception, the dualistic conception of work versus leisure time disappears. He tries to save the world from the total absolutisation of work. ${ }^{27}$ Pieper places wisdom in the spirit of paideia and educatio above the partial interests of practical life, emphasising the qualitative dimension of leisure time. The Protestant view of leisure time offered by the authors of the second tradition of post-Hellenic Christianity (including Protestant ethics), for example, L. Ryken, G. Neville, J. E. Sherrow, emphasises work and perceives leisure time as a time of rest, therapy. ${ }^{28}$ This view is based on the Protestant ethic of service to God through work. Being influenced in particular by Calvin's theology,

19 Cf. Paul HEINTZMAN, Leisure and Spirituality (biblical, historical and contemporary perspectives), Grand Rapids, Michigan: Baker Academic, 2015, p. 200.

20 Cf. PIEPER, Leisure: The Basis..., p. 28

21 Cf. Michal KAPLÁNEK, Čas volnosti - čas výchovy (Pedagogické úvahy o volném čase), Praha: Portál, 2012, p. 115.

22 Cf. Michal KAPLÁNEK, Volný čas jako výzva pro teologii, Studia Theologica 2/2021, p. 113.

23 Cf. Dana KNOTOVÁ, Pedagogická dimenze volného času, Brno: Paido, 2011, p. 31.

24 Cf. Radim PALOUŠ, Čas výchovy, Praha: Státní pedagogické nakladatelství, 1991, p. 45.

25 Sabina GÁLIKOVÁ-TOLNAIOVÁ, Problém výchovy na prahu 21. storočia, Bratislava: Iris, 2007, p. 60.

26 Cf. Klaus SCHALLER, Die Pädagogik des J. A. Comenius und die Anfänge des pädagogischen Realismus im 17. Jahrhundert, Heidelberg: Quelle \& Meyer, 1962, p. 68.

27 Cf. PIEPER, Leisure: The Basis..., p. 39.

28 Cf. HEINTZMAN, Leisure and Spirituality..., p. 203. 
it contributed to the separation of work and leisure. In comparison to work, leisure time is of secondary importance.

For Comenius, practical life represents the integration of an ordinary day into the overall meaning. He sees man especially in human activity which acts in accordance with God's order and incorporates man into the flow of God's harmony. Comenius, with the conception of man and his function in the whole of the world, transcended his epoch (anthropological starting points and the definition of man are given by Comenius in The Great Didactics). His conception of man is entirely optimistic. Comenius's man is an active and creative being. It is a person of work, movement, and activity. His activity is characterised as disciplined, methodical, planned, organised, and economic. He always keeps in mind the overall picture. ${ }^{29}$ The result of conversion in Pampaedia is not contemplative inaction, but the active participation of man in the world through his own activity, behaviour towards people, dealing with things, and through his work. ${ }^{30}$ Comenius did not perceive man a priori as a sinner. He considered him rather as a creator who has a practical interest in the world but is still related to God. Human work (ars) 'transforms the world'. It is not done arbitrarily, but rather in 'harmony with the natural essence of things'. There is a need for the synergy of human activity and God's grace. ${ }^{31}$ Primarily, Comenius's education remains an education towards humanity. It is not preparation for practical life only. Comenius was aware of the danger coming with the onset of the modern age in the area of education. It was associated with the orientation of education towards professions. He strongly warned against this. As Svobodová states: 'Comenius emphasised another knowledge. It was not the power, but the perceiving of the whole, of the meaning. This meaning is not acquired and used. Man freely relates to it. ${ }^{32}$

\section{Leisure Time and Comenius}

In Comenius's education, the classical and Protestant views on leisure time are not mutually exclusive; on the contrary, together they form a comprehensive, holistic view of leisure time. In Comenius's work, there is an oscillation between two basic demands - being and action, between two imperatives which have been faced by humanity for a time being - 'Know Yourself' (The Great Didactics) and 'Take Care of the Whole' (General Consultation on the Reform of Human Affairs). ${ }^{33}$ Comenius's concept of universal education combines knowledge and action. In Comenius, the emphasis is on being (the qualitative dimension of leisure time) through 'doing' (the quantitative dimension) in the rhythm of life, work, and rest. Work is his means of attaining the transcendental goal. Comenius's conception integrates the classical Roman Catholic understanding of leisure time as a spiritual approach (see Pieper) and the Protestant view of leisure as an activity. According to Comenius, human life is not fragmented into a number of areas (including work and leisure time). They all represent parts of the whole. Thus, we understand Comenius's concept of leisure time primarily as a state of the soul, that is, it is seen in the spirit of the spiritual dimension of leisure time. The qualitative dimension of leisure time can thus be experienced even during work. Pieper and Comenius are connected by a common spiritual approach to leisure time. It represents the rhythm of work time and leisure time. It leads to the inner integrity of the acting person who is called to serve the salvation of

29 Cf. Jaromír KOPECKÝ, Jan PATOČKA and Jiří KYRÁSEK, Jan Amos Komenský. Nástin života a díla, Praha: Státní pedagogické nakladatelství, 1957, pp. 251-252.

30 Cf. Blanka KUDLÁČOVÁ, Človek a výchova v dejinách európskeho myslenia, Trnava: PF TU, 2003, p. 88.

31 Radim PALOUŠ, Komenského Boží svět, Praha: Státní pedagogické nakladatelství, 1992, p. 70.

32 SVOBODOVÁ and BLAŠČÍKOVÁ, Mezi filosofí a teologií výchovy ..., p. 47.

33 Cf. Naděžda PELCOVÁ, Odkaz Komenského dnešku, in: Úloha osobností a institucí v rozvoji vzdělanosti v evropském kontextu, eds. Tomáš KASPER, Naděžda PELCOVÁ and Slawomir SZTOBRYN, Praha: Karolinum, 2013, p. 18. 
the universe through himself and his work - homo religiosus. ${ }^{34}$ His identity does not lie in his work roles; it is found in Jesus Christ only. Comenius's conception thus corresponds to a theologically grounded interpretation of leisure time which has two basic features - wholeness and rhythm. In the introduction to this article, we quoted Pieper's definition of leisure time as a state of the soul. Today, according to Schaller, humanity ceases to be just a 'state of the soul'. It acquires a new dimension, as, in the spirit of Comenius, it becomes necessary equipment of those whose human mission is to consult on the reform of human affairs and to actively advocate for such correction. ${ }^{35}$

\section{Whole, Humanity, and Comenius}

Comenius was an excellent didactic, but in terms of leisure pedagogy (and education as such) we put his teleology of transcendence first. The concepts of humanity and the whole, which shine through in this text, embody the main intentions of Comenius's education - conversion to the whole and humanity. To be human according to God's purpose is to live up to one's humanity. Being whole - being human - means turning to the whole in more areas. Comenius saw education as moving towards true humanity which God had ordained for him. He understood education as a process of humanisation. Comenius's entire work speaks of a whole without a margin and of man as a servant of the whole. ${ }^{36}$ It is based on the three dimensions of man: a wise creature, a master of creation, and the image of God. ${ }^{37}$ By learning, one can improve and live up to one's humanity. However, Comenius does not intend to cultivate humanity in the individual sense only. Education concerns the whole person, because man is a capax universum: he is able to grasp the whole being. ${ }^{38}$ The synthesis of Comenius's emphasis on the whole is presented by the work General Consultation on the Reform of Human Affairs, which shows the interconnectedness of the world and man and the need to see human things in the broadest context. Just like Jan Patočka, Schaller also emphasised the importance of Pampaedia, that is, Universal Education, the doctrine of making man truly human. It was Schaller who first pointed to Pampaedia as the first real educational system beyond the scope of didactics. ${ }^{39}$ Comenius's idea of lifelong learning perceives education as a lifelong process of caring for man and the whole world. According to Patočka, Comenius is a representative of the openness of the soul. The open soul sees and honours arche; it believes in the telos of the whole. After all, God is the arche and the telos of the universe. ${ }^{40}$ Openness is born in times of scholé. Comenius's education is thus a guidance to the openness of the soul for the reform of human affairs, for the salvation of the world. It is Comenius's foundation of education expressed by the intention to 'teach everyone everything'. Only when one sees (in truth) the whole world, which is important for man as the only being, is he truly human. ${ }^{41}$ The unifying leitmotif of Comenius's works is the idea of harmony in the formation of humanity of man and the whole world. According to Schaller, Comenius's 'panharmonic' is one of his most important inventions and the key to exploring the world. ${ }^{42}$ Comenius is therefore an

34 Cf. HEINTZMAN, Leisure and Spirituality..., p. 210.

35 Cf. Jana PŘÍVRATSKÁ and Vladimír PŘÍVRATSKÝ, Pojetí humanity v edukační koncepci J. A. Komenského jako př́spěvek lidské budoucnosti, Historia scholastica 2/2017, p. 20.

36 Cf. Anna HOGENOVÁ, Role celku ve filozofii J. A. Komenského a J. Patočky, in: Úloha osobností a institucí v rozvoji vzdělanosti v evropském kontextu, eds. Tomáš KASPER, Naděžda PELCOVÁ and Slawomir SZTOBRYN, Praha: Karolinum, 2013, p. 266.

37 Cf. PELCOVÁ, Odkaz Komenského..., p. 19.

38 Cf. PIEPER, Volnýčas..., p. 26.

39 Cf. Jan PATOČKA, Komeniologické studie II, Praha: OIKOYMENH, 1998, p. 214.

40 Cf. PALOUŠ, Komenského Boži svět..., p. 127.

41 Cf. Jan PATOČKA, Komeniologické studie II..., p. 355.

42 Cf. Dietmar WATERKAMP, Realism, Pansophy and Mentality in the Work of the Czech and World Pedagogue J. A. Comenius. An Analysis of Three Fundamental German Works and Their Significance for International Comeniology, International Dialogues on Education 1/2020, p. 40. Available: https://files.eric.ed.gov/fulltext/EJ1254994.pdf, cited 2. 8. 2021. 
indispensable and still current inspiration for the field of leisure pedagogy as a thinker of the whole and harmonious humanity.

\section{The Polarisation of Teaching Time and Leisure Time}

In Comenius's time, leisure time was not a topic. The division of time into periods of work, teaching, and recreation can be found even in the Middle Ages (for example, in monasteries and monastic schools) ${ }^{43}$ However, Comenius opens up a modern concept of thinking about education which, in the theory of education, takes into account the polarisation of teaching time and leisure time, the separation of working time and leisure time. Comenius devoted a space in The Great Didactics to this issue. He states there that it is not only appropriate for pupils, but even necessary to include rest breaks in addition to the daily work within the educational process. These breaks should be filled with fun, play, music, and other activities. The rhythm of work and rest, activity and leisure (including holidays) is a natural necessity in the proper establishment of good schools. In part No. VII in The Great Didactics, Comenius states: 'Let time be divided carefully, so that each year, month, day, and hour may have its own task. Let this division of time and work be kept exactly. Nothing should be left out, nothing overturned. ${ }^{44}$ From the point of view of leisure time pedagogy, the idea of the compulsory school as the birthplace of the dualism of work and leisure time appears in Comenius for the first time. ${ }^{45}$ Comenius sees the overall meaning of education (at school and during one's free time) in its Sunday determination.

\section{Comenius's Work through the Prism of the Specifics of Leisure Pedagogy}

The search for Comenius's legacy in the field of leisure time pedagogy cannot be separated from his views on the content, forms, and methods of education in teaching. They are a harmonious part of education outside of school and in leisure time. In this sense, his demand for voluntariness, motivation, and activities of students within a wide range of activities can be emphasised. He was ahead of his time with his application of humanistic pedagogical principles (especially humanism and respect for freedom) and hygiene in the educational process. His concept of universal education directly involves the issues of leisure time and education. For the first time, he presents a picture of a person's lifelong education in school and out of school. ${ }^{46}$ In his work, Comenius does not neglect care for the physical body and health. One should live a harmoniously balanced life in the intervals which include work and rest. Comenius's educational efforts were focused primarily on guiding students to humanity. Each time creates its own image of leisure time. In the terminology of contemporary leisure pedagogy, it is possible to identify a psycho-hygienic, self-realisation, formative-educational, and socialising function in Comenius. His concept can be applied to the current normative classification of leisure needs established by Horst W. Opaschowski: recreation, compensation, education, contemplation, communication, integration, participation, and enculturation. ${ }^{47}$

\footnotetext{
Cf. Michal KAPLÁNEK, Volný čas a jeho význam ve výchově, Praha: Portál, 2017, p. 46.

Jan Amos KOMENSKÝ, Didaktika velká, fundament č. VII, Praha: Knihovna pedagogických klasiků, 1905 , p. 156.

Cf. Michal KAPLÁNEK, Čas volnosti - čas výchovy, Praha: Portál, 2012, p. 33.

Cf. Emília KRATOCHVÍlOOVÁ, Pedagogika volného času, Trnava: Trnavská univerzita, 2010, p. 33.

Cf. OPASCHOWSKI, Pädagogik..., pp. 90-92.
} 


\section{Česká didaktika and Informatorium školy mateřské (Czech Didactics and Informatorium of the Kindergarten)}

Considering the works written in Czech, it is worth mentioning Česká didaktika (written 16271632) and Informatorium školy mateřské (written 1630-1632). Česká didaktika is the first systematic work about education in Europe. The school is understood here as a 'workshop of humanity'. School education is divided into four six-year phases completed at the age of 24 through the study of the academy. Education then continues in the school of life. Regarding the need for rest (recreation), Comenius states: 'The human body needs refreshment by walking, running, working, playing, and by any moving and exercising of one's body... Rest and catching of one's breath take place in some kind of action. It must be something cheerful, like fairy tales, jokes, games, music, painting, and whatever is pleasing and comfortable to the senses of the body, but without sin. ${ }^{4}$ In this work, Comenius proposes the division of the day into three parts: eight hours devoted to sleep, eight hours for eating, walking, talking, playing, and other ways of rest, and eight hours focused on work. He compares the human body to a tree: 'if it is to be alive and fresh for long periods of time, it must have a steady moisture, frequent fresh air and rest.' ${ }^{\prime 9}$ Informatorium školy mateřské is the first systematic treatise on the education of preschool children (up to six years of age) in the form of a handbook for parents and educators. It discusses the possibilities of leisure time of children. Emphasis is placed on sensory knowledge, activity, and children's natural playfulness and curiosity. In this work, Comenius sharply judges laziness ('laziness is the pillow of Satan'). He speaks about the need to involve children in games, because 'in the game, the mind is always busy with something and often sharpens itself. ${ }^{50}$ Comenius appeals to parents to organise and control their children's leisure time.

\section{Didactica magna, Didactica analytica, De rerum humanarum emendatione consultatio catholica - Pampaedia, Opera didactica omnia}

Of the works written in Latin, we will focus on the work Didactica magna (The Great Didactics, 1633-1638, published 1657), Methodus linguarum novissima (Chapter X: entitled Didactica analytica, Analytical Didactics, 1644-1648, published 1648), and De rerum humanarum emendatione consultatio catholica (General Consultation on the Reform of Human Affairs, 1645-1670). Didactica magna, published in 1657 as part of Comenius's masterpiece Opera didactica omnia (Writing on All Learning), is introduced on the title page of this collective work by the well-known motto: 'Let everything flow naturally, let there be no violence', which refers to the pursuit of harmony and tolerance. For all the principles of Comenius's didactics, the common motif is the syncritical (analogous) conformity of the didactic method with the a priori nature of the world. Didactica magna is a revised Latin version of Czech Didactics. Older encyclopaedic ideas are shifted even more significantly towards reformative efforts. In a work called Didactica analytica, focused on language education, Comenius emphasises the principle of voluntariness with regard to human nature and the free will of man. The seven-part set De rerum humanarum emendatione consultatio catholica remains an unfinished supremely pansophic (omniscient) work bearing Comenius's thought-educational legacy. The fourth part, called Pampaedia (Universal Education), becomes a tool for

48 Jan Amos KOMENSKÝ, Česká didaktika (chapter XV), in: Dílo Jana Amose Komenského II, Praha: Academia, 1973 , p. 97.

49 Ibid., chapter XV, p. 98.

50 Jan Amos KOMENSKÝ, Informatorium školy mateřské (chapter IX), in: Dílo Jana Amose Komenského II, Praha: Academia, 1973 , p. 255. 
mediating the path to perfection. He addresses all people who are to be educated in all this in a versatile way (omnes omnia omnino). All nations are to be given a general education. Comenius adds the concept of 'school of old age' and 'school of death' to the original four phases of school education. It creates a unique opportunity for the aging person to contemplate.

The whole human life becomes a school: 'Just as the whole world is a school for the whole of the human race, from the beginning of time till the very end, so the whole of a person's life is a school for every one of us, from the cradle to the grave. ${ }^{51}$ At the same time, Comenius, considering pupils, emphasises the need for games. They initiate pupils into all areas of life. It is a way to arouse students' interest and evoke the joy of learning. In Pampaedia, Comenius returns to the critique of laziness and idleness which he calls 'the state of being in the grave alive'. A lazy person or 'an idle person' resembles someone who is dead. In his time, Comenius understood the need for the holistic development of personality and argued that the most important experience is gained through the senses. His concept of teaching takes into account individual experiences. The roots of today's experiential pedagogy can be identified in his educational concept. His concept of universal education, the pansophic school, therefore significantly affects the issues of leisure time and the education of children and youth outside of the process of teaching. ${ }^{52}$

\section{Comenius's Stay in Sárospatak}

A separate chapter in the life and work of Comenius is his stay by a stream. In 1650, Comenius came with his family to Sárospatak (Muddy Stream) in Hungary, as he had received an invitation from the Rákoczi family. His task was to reform the local school in the spirit of his pansophic principles, to apply his pedagogical concept to Hungarian conditions. His ideal was a seven-class school in the pansophic spirit and the creation of textbooks for its needs. During his stay there (1650-1654), Comenius was closest in his connection with practice. This four-year period played a decisive role in the subsequent completion of his work, as he wrote his masterpiece then: the General Consultation on the Reform of Human Affairs. ${ }^{53}$ In the selection of his 'stream' writings and speeches, one can find a number of stimulating ideas about education outside the process of teaching, about the content of education and training within the pupils' leisure time, about the educator's work and its methodology. All of the texts contain Comenius's requirement for order - the order of things, people, educational tools (e.g., books), places, work, including the order of time (the division of time into parts designated for school, school breaks, and holidays).$^{54}$ Comenius considered the correct division of time to be the basis of all action. Comenius's ideas about freedom, discipline, and human nature in the teaching process and education are also inspiring for leisure pedagogy. In his view, the whole educational work was based on voluntariness. This is the basic principle of today's education in leisure time. ${ }^{55}$

He created a theoretical programme for the planned seven-class pansophic school in his work Schola pansophica (Pansophic School, Škola vševědná, 1650-1651, first published in 1651 in Sárospatak, published in 1957 as part of the General Consultation on the Reform of Human Affairs). He wanted to transform the existing school into a pansophic school. Comenius submitted a brief

51 Jan Amos KOMENSKÝ, Pampaedia, in: Obecná porada o nápravě věcí lidských III, Praha: Svoboda, 1992, p. 43.

52 Cf. Emília KRATOCHVÍlOVÁ, Pedagogika..., p. 27.

53 Cf. Josef BRAMBORA, Význam potockého pobytu pro vývoj pedagogiky a pansofie Komenského, in: Jan Amos Komenskýa Slovensko, zborník prvej slovenskej komeniologickej konferencie v Prešove 1971, ed. František KARŠAI, Košice: Východoslovenské vydavatelstvo Košice, 1971, pp. 67-72.

54 Cf. KRATOCHVÍlOVÁ, Pedagogika..., p. 29.

55 Cf. ibid., p. 33. 
concept of his reform programme entitled 'Idea světlé školy potocké' ('The Idea of the Bright Stream School') to Princess Lórantffy and Prince Rákóczi immediately after his arrival in Transylvania. In the text, Comenius states that his school is to be a school of light, an enlightened school, a workshop of humanity. He divides the subject matter into seven classes in a way that it can be then united into a single unit. In the history of pedagogy, the idea of concentration of curriculum appears for the first time. In fact, there was only a reform of the study of Latin, and only three language classes, which corresponded to three new basic Latin textbooks, were opened. ${ }^{56}$ During his teaching career in Sárospatak, Comenius also wrote his famous picture textbook Orbis sensualium pictus (The Visible World in Pictures, Svět v obrazech, 1652-1654, published in 1658).

\section{Schola pansophica}

Schola pansophica represents the first comprehensive and fully thought-out plan of a school organisation in the history of pedagogy. In the general part it deals with the mission of the school. In its seven parts it handles the subject matter, the content and organisation of teaching, the time schedule, the learning objectives, and the regime of the pupils. A special part is devoted to classroom equipment, textbooks, curricula, and methodological instructions. In the appendices, Comenius comments on other practical matters, such as securing material resources for the functioning of the school. When establishing the pansophic school, Comenius defined, as the most important requirement, a situation where 'everything should be as orderly as possible, taking into account things and people, place and time, books and works, and rest. ${ }^{\prime 5}$ In the pansophic school, Comenius divided study time into parts, each containing eight hours (as in The Great Didactics). Eight hours are to be devoted to work, eight hours to night rest, and the same number of hours should be devoted to 'one's life and rest'. Coming to the question of rest, Comenius adds: 'What does not alternate with rest cannot last. We want to practise the spirit permanently, so it is necessary to insert rest and breaks between work.58 Comenius divides the study here into first-order (main), second-order (secondary), and third-order (supplementary) studies. The content of secondary and supplementary studies addresses issues of education outside the teaching process and education in leisure time. The second-order study served as a support for the main study (study of languages, philosophy, and theology), and its content consisted of the study of history, exercises of spirit according to one's choice (exercises of senses, reason, memory, history, style, language, voice, morals, and piety), and extraordinary tasks for some students. Comenius attributed an important role to music, the singing of spiritual songs, playing a musical instrument, and reading. He included these areas in extraordinary tasks. In the case of reading, it was an extraordinary reading for smarter pupils which was based on the teacher's recommendation (in addition to compulsory reading for all pupils). In a speech delivered in November 1650 entitled 'An Oration on How to Skilfully Work with Books - the Primary Instrument in the Cultivation of Ability' he appreciated the importance of books: 'The candidate of education should value books over gold and precious stones and collect pollen obtained from noble science from and transfer it to the hive of his own education. ${ }^{59}$ He presents methodological recommendations for working with a book

56 Cf. Jozef PŠENÁK, Význam potockého pobytu pre vývoj pedagogiky Komenského, Pedagogika, časopis pro pedagogické vědy 5-6/1991, pp. 593-600.

57 Jan Amos KOMENSKÝ, Škola vševědná, in: Vybrané spisy Jana Amose Komenského II, Praha: Státní pedagogické nakladatelství, 1960, p. 35 .

58 KOMENSKÝ, Škola vševědná..., p. 55.

59 Ibid., p. 145. 
(e.g., taking notes) during and outside classes. At the same time, he appreciates the importance of school libraries (especially for poor students). The study of the third order (supplementary) was a study 'which does not affect the inner education of the spirit, but rather the external physical agility and thus the activation and promotion of mental freshness. ${ }^{60}$ Comenius included various plays, stage performances, and theatre in this group.

\section{Regulations for a Well-ordered School}

According to Comenius, the basis of school improvement is exact order in everything. Order is the soul of things, and our ideal is nature. From Comenius's 'stream' writings and speeches, we select the following laws (leges), as provisions of the school rules, important stimuli for the pedagogy of leisure time. Regulations for a Well-ordered School (Leges scholae bene ordinate) contain a general overview of the functioning of the pansophic school. In the introductory greeting, Comenius justifies his conception of regulations as leges, recalling the ancient Greek wisdom: 'Whoever wants the community to be destroyed, let him break down its order.'61 The school needs to be fortified through laws. The overall text also contains forms and methods of working with students which, today, belong to education outside the teaching process. Within the laws, requirements are set that correspond to today's pedagogical, psychological, and hygienic requirements for the educational process. Comenius prescribes laws concerning ways of resting here. Part of the pansophic school was also education outside the classroom and in the leisure time of pupils which was taken care of by teachers and educators. Comenius also draws up laws for boarding schools and canteens. A large part of the pupils lived in a boarding school set up at the school, as the distance to their various residences was considerable. The text also includes a general treatise on theatrical performances. In Regulations for a Well-ordered School, in Chapter IV (which is entitled 'Regulations for the Appropriate Distribution of Time') Comenius requires regular division of time for work and rest in days, weeks, months, and years. After each lesson (after reaching a certain goal), there is time for a half-hour break. In addition to classes, there should be time for practice in piety (one hour in the morning), repetition of school curriculum (after school), and time for fun in music or math (after lunch). The remaining time will be 'spare time for housework, decent rest, and private study'. Holidays will be four times a year - always in connection with Christian holidays (Christmas, Easter, Whitsun - always eight days before and eight days after), and a whole month during the vintage: 'Where there is no vintage, holidays can be during the hot days of July.62 The content of Chapter IX entitled 'Regulations for Theatre Performances' and Chapter X called 'Regulations for Resting Time' will be discussed below in the description of the role of play and theatre in Comenius's pedagogical concept. Chapter XX, entitled 'Regulations for Pedagogy and Educators', contains the requirements for this profession. The educators' task is to supervise the behaviour of students, to cultivate their piety, to educate their minds and language in mutual conversations with them, and to lead them toward the achievement of good grades. These are private educators of noble sons or older students appointed by the director. Comenius placed considerable demands on educators in terms of personal qualities and level of education: 'Everyone must strive to achieve (above all and especially) the qualities which he wants to grow in his students - to be educated, moral, and pious without pretence. ${ }^{63}$ 


\section{Games}

As already stated, Comenius in the pansophic school proposes studies with a schedule of phases consisting of rest and regeneration in play and entertainment. We meet the concept of the role of game in more detail in The Great Didactics. A game is used by pupils to recover and develop certain habits, 'because the tools can be used to imitate crafts, farm work, civic activities, military installations, construction, and others. Only then will schools become a prelude to life. ${ }^{64}$ The educational use of games has the nature of direct, purposeful, and intentional preparation for life. At the same time, the function of a game is understood in terms of rest and refreshment. Rest and play should follow only after serious work. ${ }^{65}$ These are out-of-school games, outside the school walls: 'When it is time to learn, you have to return to school and leave the game. ${ }^{66}$ Comenius understands games mainly as a recreational activity, as stated in Regulations for a Well-ordered School in Chapter X, entitled 'Regulations for the time of rest. ${ }^{67}$ Preschool children's games listed in Informatorium of the Kindergarten are characterised by physical movement. After the first six years of life, a game mainly fulfils the function of rest. That is why Comenius gives it space after class or during breaks between classes (only some of its features are applied during classes). In adulthood, a game is to serve as a harmonising element for the acquisition of physical or mental strength. ${ }^{68}$ In Pansophic School, Comenius placed the classification of games. It distinguishes between movement games (running, jumping, racing, playing with a ball, ball or cone, playing blind man's buff, and also a walk in a group) and board games which are used to develop thinking (chess). Prohibited games include playing cards and dice, as they are decided by chance and some players may be concerned about the outcome. ${ }^{69}$ In Rules of Conduct for Young Men (collected for young people in 1653), Comenius expands this list and includes wrestling, fencing, and swimming in water, as these are 'useless and dangerous things. ${ }^{30}$ According to Jana Uhlírová, Comenius sees the meaning of games in the development of various areas of human personality. These are: a physiological area (health, fitness); character traits (honesty, truthfulness); activity, wit, alertness and acumen; development of knowledge, emotion, criticality; solidarity, humanity, and non-violence. ${ }^{71}$

\section{Theatre}

In Comenius, a special form of play was theatre. In his time, it was widely used as a means of teaching, especially in Jesuit education. Comenius called his own plays ludus. Theatrical plays served Comenius exclusively as a pedagogical and didactic means for acquiring certain knowledge (in an entertaining way) and for strengthening the motivation of pupils (with the use of the element of illustration and pupils' own activity). His school theatre relied on dialogue as one of the forms of illustration. In Chapter X of Regulations for a Well-ordered School Comenius sets out the regulations on theatrical performances. The theatre is a part of the main studies in the pansophic school. Due to the fact that the whole theatre could not be rehearsed at the time of teaching, it became part of the activities outside of teaching. ${ }^{72}$ The school theatre presented dialogised processing of texts that

64 Jan Amos KOMENSKÝ, Velká didaktika..., p. 176.

65 Cf. Jana UHLÍŘOVÁ, Role hry v Komenského pedagogické koncepci, Praha: Univerzita Karlova, Pedagogická fakulta, 2003 , p. 26.

66 Jan Amos KOMENSKÝ, Vybrané spisy Jana Amose Komenského II..., pp. 255-266.

67 KOMENSKÝ, Škola vševědná..., pp. 277-278.

68 Cf. UHLÍŘOVÁ, Role hry..., p. 46.

69 KOMENSKÝ, Škola vševědná..., p. 53.

70 KOMENSKÝ, Škola vševědná..., p. 265.

71 UHLÍŘOVÁ, Role hry..., p. 26.

72 Cf. Milan PŘADKA, Kapitoly z dějin pedagogiky volného času, Brno: Masarykova univerzita, 2002, p. 17. 
were the subject of school teaching. Demonstration of certain facts in a dialogised form on stage is one of the highest forms of illustration in teaching in Comenius's time. ${ }^{73}$ The ensemble of dramas Schola ludus (Škola na jevišti, Škola hrou, School by Play, 1654, published in 1656), the dramatisation of Janua Lingvarum's material, represents his own theatrical production from the Sárospatak period. In the Latin secondary school, school theatre becomes a method of education. At present, the means of drama education and staging methods are used in the educational process and elsewhere. They are part of experiential learning and education through experience and in the pedagogy of leisure time.

\section{Critique of Laziness}

As in previous works, Comenius's work from Sárospatak is critical of the laziness in schools. $\mathrm{He}$ was witnessing this issue in the local school in some pupils and teachers. There, he wrote the work Fortius redivivus sive De pellenda scholis ignavia (Oživlý Fortius aneb Jak vyhnat ze škol lenost, Fortius once again Alive or How to Eliminate Laziness from Schools, 1652, published in 1652). According to him, the right school is not a place of rest and free entertainment, but a workshop of humanity, wisdom, and light. Its greatest enemy is ingrained laziness, a 'destructive and clumsy monster. ${ }^{74}$ The schools of laziness produce 'broken work instead of beautiful statues, smouldering butts instead of the light of the world, lush goats instead of the purest lambs, thorny bushes instead of fertile trees. ${ }^{75}$ Addressing an uneducated teacher, Comenius adds that 'as a lazy leader of others, he is nothing but a shadow without a thing, a cloud without water, a well without a spring, a lamp without light. ${ }^{76}$

\section{Postmodern Times}

The pedagogy of leisure time as a starting point leading from school labyrinths to open space is becoming an authentic space for the call for holistic education in the third millennium. This metaphorical expression captures the way used during the studies of Comenius's final thoughts on the reform of education which are in the book Scholarum Reformator Pansophicus (Pansoficky vychovatel, 1657-1658). The contemporary postmodern world is a labyrinth of meanings, values, and contexts; the labyrinth is a symbol of relativity. Man is confused by the multiplicity and fragmentation of approaches to everything. The huge accumulation of information results in the situation where the world as a unity and a whole is rather moving away from man. Instead of belonging to the whole, one turns to oneself. There is a dichotomy between work and leisure, acting and being. Life revolves around leisure time activities and the market with goods for leisure time. Homo faber serves Homo ludus and vice versa to produce the predominant man of the postmodern period - Homo consumericus. ${ }^{77}$ The 'school' labyrinth also corresponds to the labyrinth of the world. The teaching of facts, in the sense of prefabricated data, often dominates school teaching. Pupils receive 'instant' knowledge intended for knowledge only. General knowledge is often characterised by specialisation at the expense of wholeness. Schools are often reduced to service institutions which are deprived of any transcendence and serves, primarily, the requirements of the market. Pupil preparation is often focused on partial goals, life purposes. The requirement of the time is therefore to lead the person/

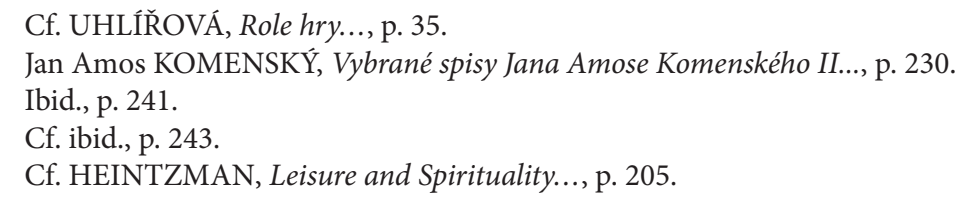


pupil out of the labyrinth to the open space, to open him up to the whole. In the open space, one should learn what existence wants. There should be harmony with nature and with oneself in the wholeness of the world. One should learn to feel sacred, to experience authentic joy. One should return to the essential enquiry, awaken the good in one's soul, and meet the insubstantial whole (without margo) in the form of the Platonic Good or the Christian God.

\section{The Topicality of the Significance of Comenius's Legacy for Leisure Time Pedagogy}

That Ariadne's thread, which can help the pupil find the way out of the labyrinth (pull him out of the entanglement in the individual elements, lead him to the whole and the meaning of his own existence, and save his right to freedom of 'living from his own foundation, from his own source ${ }^{378}$ ), is the return to Sunday's determination of upbringing and education, the restoration of the original meaning of scholé. Scholé, in a sense of determining a free, independent space for listening to the essential challenge, is also a challenge for the current pedagogy of leisure time. This should become the guardian of scholé, the protector of the whole, and the helper in the renewal of humanity. Leisure time pedagogy, as an education with psychagogic aspects, has a philosophical-religious dimension. Its focus is on understanding the human world as valuable, spiritual, meaningful. It is connected with an inspiring care for the lifelong stimulation of the human soul and its movement within the holistic concept of human life. In such a concept, all aspects of life, including the rhythm of work and leisure time, are understood as an integral part of the whole. We perceive his philosophical legacy especially in the perspective of his intellectual heritage; we see him as the thinker of the whole. His legacy of the theologian we see in the spiritual dimension of leisure time pedagogy. His legacy of the pedagogue can be seen in the usefulness of his timeless didactic theory. Without the transcendence of humanity, on which his philosophy of education is based, the contemporary pedagogical humanisation would be difficult to implement. We wish the pedagogy of leisure time, as a new phenomenon, to have a chance to support its development in our country, the country of Comenius. This 'pilgrim at the turn of the time', still alive and present due to his work, could help us restore the much-needed original meaning of the school - scholé. Ex labyrintho ad Unum!

\section{Contact}

Assoc. Prof. PhDr. Helena Zbudilová, Ph.D. University of South Bohemia in České Budějovice

Faculty of Theology

Department of Education

Kněžská 8, 37001 České Budějovice

hzbudilova@tf.jcu.cz

78 Anna HOGENOVÁ, Michal SLANINKA, Žit z vlastního pramene (Rozhovory o životě a filozofii s A. Hogenovou), Praha: Malvern, 2019, p. 13. 